\title{
Amoebiasis distribution in the past: first steps using an immunoassay technique
}

\author{
Marcelo Luiz Carvalho Goncalves a , Valmir Laurentino da Silva ${ }^{a}$, \\ Carlos Mauricio de Andrade ${ }^{\mathrm{a}}$, Karl Reinhard ${ }^{\mathrm{b}}$, Gino Chaves da Rocha ${ }^{\mathrm{a}, \mathrm{c}}$, \\ Matthieu Le Baillyc ${ }^{c}$, Francoise Bouchet ${ }^{c}$, Luiz Fernando Ferreira ${ }^{a}$, \\ Adauto Araujo ${ }^{\mathrm{a}, *}$
}

a Escola Nacional de Saude Publica, Fundacao Oswaldo Cruz, Rua Leopoldo Bulhoes 1480, CEP 21041-210, Rio de Janeiro, Brazil

${ }^{\mathrm{b}}$ School of Natural Resource Sciences, University of Nebraska, Lincoln, NE, USA

' Laboratoire de Paleoparasitologie EA3308, associe CNRS ESA 8045, U. F. R. de Pharmacie, Universite de Reims, Reims, France

Received 28 March 2003; received in revised form 28 July 2003; accepted 1 August 2003

\section{KEYWORDS \\ Paleoparasitology; \\ Coprolites; \\ Ancient faeces; \\ Amebiasis; \\ ELISA}

\begin{abstract}
Summary The identification of parasites in ancient human faeces is compromised by differential preservation of identifiable parasite structures. However, protein molecules can survive the damage of the environment and can be detected even after centuries. In this paper it is shown that is possible to detect copro-antigen of Entamoeba histolytica in historic and prehistoric human faecal remains, using a commercially available enzyme immunoassay (ELISA) kit. The kit uses monoclonal antibody-peroxidase conjugate specific for $E$. histolytica adhesin. A total of 90 specimens of desiccated faeces found in mummies and ancient organic sediment from South America, North America, Africa, and Europe were examined. The ELISA detected 20 positive samples, dated to about 5300 years before present to the 19 th Century ad. The positive samples are from archaeological sites in Argentina, USA, France, Belgium, and Switzerland. The detection of protozoan antigen using immunoassays is a reliable tool for the studies of intestinal parasites in the past.

(c) 2003 Royal Society of Tropical Medicine and Hygiene. Published by Elsevier Ltd. All rights reserved.
\end{abstract}

\section{Introduction}

Different species of parasites have been found in preserved human faecal material from historic and prehistoric times throughout the world. Many findings of nematodes, trematodes, cestodes and acanthocephalan eggs in archaeological material are

*Corresponding author. Fax: +55-21-25982610.

E-mail address: adauto@ensp.fiocruz.br (A. Araujo). available in the literature. A review of the paleoparasitological findings has been made by Reinhard et al. (1986), Reinhard (1990) and Goncalves et al. (2003). Such findings have been made possible through the study of organic sediment from ancient cesspits and desiccated faecal material collected from mummies or found during archaeological excavations. Desiccated faeces are called coprolites. Paleoparasitology is the study of parasites in such archaeological material. 
Protozoan detection in coprolites, on the contrary, is not a frequent finding in paleoparasitology (Reinhard et al., 1986; Goncalves et al., 2003). Unlike helminth eggs, cysts quickly decay in the environmental conditions of archaeological sites, and are very difficult to find by direct microscopic examination.

However, protozoan antigens remain detectable for longer periods of time. Faulkner et al. (1989) and Allison et al. (1999) succeeded in finding Giardia duodenalis antigen using immunological techniques in material as old as 2177 and 3000 years respectively. The use of enzyme-linked immunosorbent assay (ELISA) using monoclonal antibodies has been useful in the detection of protozoan copro-antigen in ancient faecal samples. Goncalves et al. (2002) detected Giardia Specific Antigen 65 (GSA65) in coprolites and latrine sediments dated from 1200 ad to $1700 \mathrm{ad}$.

Several studies have found ELISA to be a tool with very high sensitivity and specificity for Entamoeba histolytica copro-antigen detection in fresh faeces
(Haque et al., 1995, 1998; Pillai et al., 1999; Garcia et al., 2000; Haque et al., 2000; Sharp et al., 2001). We conducted a study to assess the feasibility of the detection of $E$. histolytica in ancient human remains using a commercially available enzyme immunoassay. The kit uses monoclonal antibody to detect specific $E$. histolytica adhesin in faecal samples.

\section{Materials and methods}

\subsection{Specimens}

A total of 90 coprolites and sediment samples from South America, North America, Africa, and Europe were tested for $E$. histolytica adhesin antigen. Their origins are listed in Table 1. The samples have been dated either by ${ }^{14} \mathrm{C}$ method or by cultural context. All samples used were rehydrated by immersion in a $0.5 \%$ trisodium phosphate aqueous solution for $72 \mathrm{~h}$ (Callen and Cameron, 1960). Raillet-Henry solution

Table 1 Country, archaeological site, type and number of samples, age, and positive results ${ }^{\mathrm{a}}$ for Entamoeba histolytica antigen

\begin{tabular}{|c|c|c|c|c|c|}
\hline Country & Archaeological site & $\begin{array}{l}\text { Type of } \\
\text { sample }\end{array}$ & $\begin{array}{l}\text { Number of } \\
\text { samples }\end{array}$ & Age & $\begin{array}{l}\text { Number of } \\
\text { positive } \\
\text { samples }\end{array}$ \\
\hline Argentina & $\begin{array}{l}\text { Fortin Minana } \\
\text { Neuquen }\end{array}$ & $\begin{array}{l}\text { cesspit A } \\
\text { cesspit B } \\
\text { coprolite }\end{array}$ & $\begin{array}{l}7 \\
4 \\
2\end{array}$ & $\begin{array}{l}\text { 19th Century ad } \\
19 \text { th Century ad } \\
1000-500 \mathrm{BP}\end{array}$ & $\begin{array}{l}7 \\
2 \\
0\end{array}$ \\
\hline Belgium & Namur & $\begin{array}{l}\text { cesspit } \\
\text { cesspit } \\
\text { cesspit } \\
\text { cesspit }\end{array}$ & $\begin{array}{l}4 \\
3 \\
2 \\
3\end{array}$ & $\begin{array}{l}\text { 9th-11th Century ad } \\
\text { 14th Century ad } \\
\text { 15th-17th Century ad } \\
\text { 18th Century ad }\end{array}$ & $\begin{array}{l}0 \\
1 \\
0 \\
1\end{array}$ \\
\hline Brazil & $\begin{array}{l}\text { Serra da Capivara } \\
\text { São Domingos } \\
\text { Santa Elina }\end{array}$ & $\begin{array}{l}\text { coprolite } \\
\text { coprolite } \\
\text { coprolite }\end{array}$ & $\begin{array}{l}7 \\
1 \\
1\end{array}$ & $\begin{array}{l}8760 \mathrm{BP}^{\mathrm{b}} \\
6000-5000 \mathrm{BP} \mathrm{P}^{\mathrm{b}} \\
4000-2000 \mathrm{BP}^{\mathrm{b}}\end{array}$ & $\begin{array}{l}0 \\
0 \\
0\end{array}$ \\
\hline Chile & $\begin{array}{l}\text { San Pedro de Atacama } \\
\text { Iquique }\end{array}$ & $\begin{array}{l}\text { coprolite } \\
\text { coprolite }\end{array}$ & $\begin{array}{l}7 \\
1\end{array}$ & $\begin{array}{l}3080-2950 B P^{b} \\
6110-3950 \mathrm{BP}^{\mathrm{b}}\end{array}$ & $\begin{array}{l}0 \\
0\end{array}$ \\
\hline France & $\begin{array}{l}\text { Castillon-du-Gard } \\
\text { Gresine } \\
\text { Montbeliard }\end{array}$ & $\begin{array}{l}\text { cesspit } \\
\text { sediment } \\
\text { cesspit }\end{array}$ & $\begin{array}{r}14 \\
5 \\
1\end{array}$ & $\begin{array}{l}\text { 3rd Century ad } \\
2500 \text { BP } \\
\text { 15th-16th Century ad }\end{array}$ & $\begin{array}{l}2 \\
1 \\
0\end{array}$ \\
\hline Germany & Lubeck & cesspit & 1 & 15th Century ad & 0 \\
\hline Sudan & Sai & coprolite & 5 & $2700-2330 \mathrm{BPb}$ and $1700-500 \mathrm{BP}$ & 0 \\
\hline Switzerland & Arbon & sediment & 5 & $5300 \mathrm{BPb}$ & 3 \\
\hline USA & Canyon De Chelly & $\begin{array}{l}\text { cesspit } \\
\text { cesspit }\end{array}$ & $\begin{array}{r}4 \\
13\end{array}$ & $\begin{array}{l}1100-800 \mathrm{BP}^{\mathrm{b}} \\
800-700 \mathrm{BPb}\end{array}$ & $\begin{array}{l}0 \\
3\end{array}$ \\
\hline
\end{tabular}

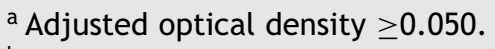

${ }^{b} \mathrm{BP}$, before present. 
( $920 \mathrm{ml} \mathrm{NaCl} 0.8 \%-30 \mathrm{ml}$ formalin $40 \%-50 \mathrm{ml}$ glacial acetic acid) was added to each rehydrated sample in a proportion of $1: 10$ to avoid fungal and bacterial growth. All samples were microscopically examined for parasite remains following standard techniques.

\subsection{Enzyme-linked immunosorbent assay}

The E. histolytica II assay (TechLab, Blackburg, VA, USA) was used according to the manufacturer's directions. Each test well was inoculated with $400 \mu \mathrm{l}$ of sediment from a rehydrated sample solution. Results were interpreted by visual inspection and by a spectrophotometer. A test sample was considered positive if it had an obvious yellow color when compared to the negative control well. A test sample was considered negative if it was colorless or less yellow than the negative control well. The absorbance of each specimen was measured at $450 \mathrm{~nm}$ wavelength. The values were adjusted by subtracting the optical density of the negative control from the optical density of the samples. According to the instructions, samples with adjusted optical density $\geq 0.050$ were considered positive.

\section{Results}

A total of 20 samples (22.2\%) were positive for $E$. histolytica antigen. The positive immunoassay results are shown in the Table 1 . Visual and spectrophotometer readings were concordant in all samples. All samples but 1 were negative for protozoan cysts by microscopy. As previously reported, $G$. duodenalis were found in 1 sample from the archaeological site of Namur, Belgium (Goncalves et al., 2002).

\section{Discussion}

The former species $E$. histolytica was separated in 1993 into two morphologically identical species, $E$. dispar, a non-pathogenic intestinal parasite and $E$. histolytica, that can cause dysentery and extraintestinal disease in humans (Diamond and Clark, 1993).

Although microscopy can not differentiate between these two species, isoenzyme analysis and specific molecular techniques are able to distinguish $E$. histolytica from E. dispar (Haque et al., 1998; Huston et al., 1999). Molecular techniques include polymerase chain reaction (PCR) and detection of $E$. histolytica-specific antigen using enzyme-linked immunosorbent assay. Antigenic differences between the lectins of each species make possible the differentiation. Stool amoebic lectin detection by ELISA has been shown to be a cost-effective and rapid method for detection of $E$. histolytica in stool specimens (Huston et al., 1999; Haque et al., 2000).

We used a commercially available immunoassay to detect an amoebic adherence lectin that is inhibitable by $\mathrm{D}$-galactose (Gal) or $\mathrm{N}$-acetyl-D-galac - tosamine (GalNAC). This high immunogenic molecule is a major amoebic surface protein (Petri et al., 1988; Gaucher and Chadee, 2002). Antigenic differences in Gal/GalNAc lectins of $E$. dispar and $E$. histolytica make possible the specific diagnostic by using monoclonal antibodies (Huston et al., 1999). The kit uses a monoclonal antibody against the $E$. histolytica adhesin. The sensitivity and the specificity of the method varies from $96.9 \%$ to $100 \%$ and $94.7 \%$ to $100 \%$, respectively, when compared with culture of stool samples and isoenzyme analysis, according to the manufacturer. Haque et al. (2000), in a cross-sectional study, report that the kit identified all 16 of the culture-positive samples in a 1164 preschool children, as well as 34 negative culture samples. Using a PCR technique, they detected $E$. histolytica in 27 of these 34 samples.

According to the kit manufacturer, the immunoassay is able to detect approximately 0.2 to $0.4 \mathrm{ng}$ of adhesin per well. The protein epitopes from the $E$. histolytica lectin can remain stable for at least 5300 years, as assessed by our findings from Switzerland. However, caution should be exerted in the interpretation of negative results in ancient samples as antigen structure may be compromised due to uncontrolled environment conditions.

Beck et al. (2002) have demonstrated genetic conservation of the Gal/GalNAc lectin between $E$. histolytica isolates from Bangladesh and Georgia. They argued that $E$. histolytica could be a clonal population. Similar studies using samples five thousand years apart could clarify such evolutionary questions.

We could detect $E$. histolytica antigen in human faecal residues from a wide array of times throughout the world, reflecting the ubiquity of this parasite. E. histolytica can infect apes and other primates. However, it is unlikely that we confused non-human primate faeces with human faeces since humans are the only primates that inhabited the study areas in Europe and North America.

In the New World, we detected positive samples in cesspits from Fortin Minana (Argentina), a small military settlement at the countryside in Buenos Aires Province, used during the second half of 19th century. Samples from cesspits of Anasazi culture, Canyon De Chelly (USA), dated from 1200 to 1300 ad, were also positive. 
In the Old World, we detected positive samples from cesspits of a roman villa called La Gramiere, at Castillon-du-Gard, France, occupied from the Roman Period until the High Medieval Period, and also from medieval latrines from Place D'Armes, in Namur, Belgium. E. histolytica antigen was also found in organic sediment of a Neolithic settlement close to Lake Constance, in Arbon, Switzerland, and from a Bronze Age settlement in Bourget lake, Gresine, France. References about the archaeological sites can be found in the paleoparasitological review of Goncalves et al. (2003).

Although a very common parasite worldwide, the finding of amoebic cysts in ancient human faeces is very rare, probably due to a faster decay than helminth eggs and larvae. The utility of this technique, combined with a new generation of molecular methods, will reveal the temporal and spatial distribution of protozoan parasites in ancient times.

\section{Acknowledgements}

This study was supported by the Brazilian Research Council (Projetos de Excelencia/Conselho Nacional de Pesquisa), CAPES/COFECUB (Comité Français d'Evaluation de la Coopération Universitaire avec le Brésil/Coordenação de Aperfeicoamento de Pessoal de Nivel Superior), the Fulbright Foundation and CNRS (Centre Nationale de la Recherche Scientifique, France).

\section{References}

Allison, M.J., Bergman, T., Gerszten, E., 1999. Further studies on faecal parasites in Antiquity. Am. J. Clin. Pathol. 112, 605-609.

Beck, D.L., Tanyuksel, M., Mackey, A.J., Haque, R., Trapaidze, N., Pearson, W.R., Loftus, B., Petri, W.A., 2002. Entamoeba histolytica: sequence conservation of the Gal/GalNAC lectin from clinical isolates. Exp. Parasitol. 101, 157163.

Callen, E.O., Cameron, T.W.M., 1960. A prehistoric diet as revealed in coprolites. New Scientist 8, 35-40.

Diamond, L.S., Clark, C.G., 1993. A redescription of Entamoeba histolytica Shaudinn, 1903 (amended Walker, 1911) separating it from Entamoeba dispar Brumpt, 1925. J. Euk. Microbiol. 40, 340-344.
Faulkner, C.T., Sharon, P., Johnson, S.S., 1989. Prehistoric parasitism in Tennessee: evidence from the analysis of desiccated faecal material collected from Big Bone cave, Van Buren, Tennessee. J. Parasitol. 75, 461-463.

Garcia, L.S., Shimizu, R.Y., Bernard, C.N., 2000. Detection of Giardia lamblia, Entamoeba histolytica/Entamoeba dispar, and Cryptosporidium parvum antigens in human faecal specimens using the triage parasite panel enzyme immunoassay. J. Clin. Microbiol. 38, 3337-3340.

Gaucher, D., Chadee, K., 2002. Construction and immunogenicity of a codon-optimized Entamoeba histolytica Gal-lectinbased DNA vaccine. Vaccine 20, 3244-3253.

Goncalves, M.L.C., Araujo, A., Duarte, R., Silva, J.P., Reinhard, K., Bouchet, F., Ferreira, L.F., 2002. Detection of Giardia duodenalis antigen in coprolites using a commercially available enzyme immunoassay. Trans. R. Soc. Trop. Med. Hyg. 96, 640-643.

Goncalves, M.L.C., Araujo, A., Ferreira, L.F., 2003. Human intestinal parasites in the past: new findings and a review. Mem. Inst. Oswaldo Cruz 98(Suppl. I), 103-118.

Haque, R., Neville, L.M., Hahn, P., Petri Jr., W.A., 1995. Rapid diagnosis of Entamoeba infection by using Entamoeba and Entamoeba histolytica stool antigen detection kits. J. Clin. Microbiol. 33, 2558-2561.

Haque, R., Ali, I.K.M., Akther, S., Petri Jr., W.A., 1998. Comparison of PCR, isoenzyme analysis, and antigen detection for diagnosis of Entamoeba histolytica infection. J. Clin. Microbiol. 36, 449-452.

Haque, R., Mollah, N.U., Ali, I.K.M., Alam, K., Eubanks, A., Lyerly, D., Petri Jr., W.A., 2000. Diagnosis of amebic liver abscess and intestinal infection with the Techlab Entamoeba histolytica II antigen detection and antibody tests. J. Clin. Microbiol. 38, 3235-3239.

Huston, C.D., Haque, R., Petri Jr., W.A., 1999. Molecular-based diagnosis of Entamoeba histolytica infection, Expert Rev. Mol. Med. 22 March, http://www-ermm.cbcu.cam.ac.uk/ 99000599h.htm.

Petri Jr., W.A., Smith, R.D., Schesinger, P.H., Murphy, C.F., Ravdin, J.I., 1988. Isolation of the galactose-binding lectin that mediates the in vitro adherence of Entamoeba histolytica. J. Clin. Invest. 80, 1238-1244.

Pillai, D.R., Keystone, J.S., Sheppard, D.C., MacLean, J.D., MacPherson, D.W., Kain, K.C., 1999. Entamoeba histolytica and Entamoeba dispar: epidemiology and comparison of diagnostic methods in a setting of nonendemicity. Clin. Infect. Dis. 29, 1315-1318.

Reinhard, K.J., 1990. Archaeoparasitology in North America. Am. J. Phys. Anthropol. 82, 145-162.

Reinhard, K.J., Confalonieri, U., Herrmann, B., Ferreira, L.F., Araujo, A., 1986. Recovery of parasite remains from coprolites and latrines: aspects of paleoparasitological technique. Homo 37, 217-239.

Sharp, S.E., Suarez, C.A., Duran, Y., Poppiti, R.J., 2001. Evaluation of the Triage Micro Parasite Panel for detection of Giardia lamblia, Entamoeba histolytica/Entamoeba dispar, and Cryptosporidium parvum in patient stool specimens. J. Clin. Microbiol. 39, 332-334.

\footnotetext{
Available online at www.sciencedirect.com

science@direct。
} 